\title{
Perilaku Pemanfaatan Layanan Voluntary Counseling And Testing (VCT) pada Ibu Hamil
}

\author{
Siti Widya Rahayu Wibowo ${ }^{1}$, Irma Jayatmi ${ }^{2}$ \\ ${ }^{1}$ Puskesmas Wanaraja \\ ${ }^{2}$ Sekolah Tinggi Ilmu Kesehatan Indonesia Maju \\ Email: siti_widyarahayuwibow@gmail.com ${ }^{1}$,irma.jayatmi@stikim.ac.id ${ }^{2}$
}

\begin{abstract}
Abstrak
Tujuan penelitian ini adalah untuk mengetahui pengaruh sumber informasi, fasilitas pelayanan, peran kader dan motivasi ibu hamil terhadap perilaku pemanfaatan layanan VCT pada ibu hamil diwilayah Puskesmas Siliwangi Kabupaten Garut tahun 2015. Metode yang digunakan dalam penelitian ini adalah cross sectional, yaitu arah melintang dengan menggunakan sampel 75 responden dari populasi masyakarat. Dan alat pengumpulan data adalah instrumen kuisioner dengan model pertanyaan tertutup. Sedang teknik analisis menggunakan pendekatan kuantitatif dengan analisis menggunakan Structural Equation Modelling (SEM) dengan aplikasi software smart PLS dan Special Package for Statistis Science (SPSS). Hasil penelitian menunjukan adanya pengaruh antar variabel penelitian dan dengan pemodelan SEM dengan masing-masing memberikan nilai kontribusi masingmasing memberikan nilai kontribusi dan nilai variabilitas data sebesar $96,45 \%$ sehingga ada 6.48 faktor lain yang tidak diteliti. Berdasarkan hasil perhitungan juga, pengaruh langsung antara peran kader terhadap perilaku pemanfaatan layanan VCT didapat temuan angka tertinggi dengan nilai pengaruh langsung sebesar $27,154 \%$ dan pengaruh tidak langsung sebesar 0,027 melalui variabel motivasi dan fasilitas kesehatan. Disimpulkan bahwa variabel peran kader memiliki nilai tertinggi terhadap perilaku pemanfaatan layanan VCT, sehingga disarankan melakukan pelatihan layanan VCT berbasis masyarakat.
\end{abstract}

Kata Kunci: Motivasi, Peran, Sumber Informasi

\begin{abstract}
The purpose of this study was to determine the effect of resources, service facilities, the role of cadres and motivation of pregnant women on the behavior of the utilization of VCT services to pregnant women in the region Puskesmas Siliwangi Garut in 2015. The method used in this study was cross sectional, ie transverse direction by using sample of 75 respondents from the population of the community. And data collection tool is a questionnaire instrument model with closed questions. Medium analysis technique using a quantitative approach to the analysis using Structural Equation Modelling (SEM) with smart software applications PLS and the Special Package for statistical Science (SPSS). The results showed an effect between the variables and the modeling SEM with each value the contribution of each value the contribution and value of $96.45 \%$ of the variability of the data so that no other factor 6:48 is not examined. Based on the calculation, too, a direct influence on the behavior of cadres between the role of the utilization of VCT services obtained the highest number of findings directly influence the value of 27.154\% and amounted to 0,027 indirect effect through motivational variables and health facilities. Concluded that the variable role volunteers have the highest scores on the behavior of the utilization of VCT services, so it is advisable training community-based VCT services.
\end{abstract}

Keywords: Motivation, Roles, Resources 


\section{Pendahuluan}

$M D G s$ telah menjadi referensi penting pembangunan di Indonesia, mulai dari tahap perencanaan seperti yang tercantum pada Rencana Pembangunan Jangka Menengah (RPJM) hingga pelaksanaannya. Walaupun mengalamai kendala, namun pemerintah memiliki komitmen untuk melaksanakan serta bekerjasama dengan seluruh pihak, termasuk masyarakat MDGs di Indonesia akan dijadikan dasar untuk perjanjian kerjasama dan implementasinya dimasa depan. Hal ini termasuk kampanye untuk perjanjian tukar guling hutang untuk negara berkembang sejalan dengan Deklarasi Jakarta mengenai MDGs di daerah Asia dan Pasifik. ${ }^{1}$ Kementrian Kesehatan (Kemenkes) RI, hingga akhir September tahun 2014 terjadi kasus HIV sebanyak 7.335 kasus, walaupun angka ini meningkat dibanding tahun sebelumnya pada tahun 2009 sebanyak 6.073 kasus, pada tahun 2010 sebanyak 6.907 kasus, pada tahun 2011 sebanyak 7.312 kasus, pada tahun 2012 sebanyak 8.747 kasus, dan pada tahun 2013 sebanyak 6.266 kasus. $^{2}$ Sampai tahun 2011 organisasi kesehatan dunia (WHO) mencatat jumlah penderita HIV/AIDS di seluruh dunia meningkat jumlahnya hingga mencapai 5,2 juta jiwa. Padahal pada tahun 2010 hanya 1,2 juta jiwa (Kampung TKI, 2011). Hingga akhhir tahun 2010 lalu data dari Kemkes menunjukkan ada 14.865 penderita HIV dan 3.863 penderita AIDS di tahun 2009. Sedangkan tahun 2010 penderita HIV ada 15.275 dan AIDS sejumlah 4.158. Secara akumulatif mulai dari April 1987 hingga September 2010 jumlah penderita HIV/AIDS di Indonesia telah mencapai 22.726 kasus dengan angka kematian 4.249 orang Departemen Kesehatan RI memperkirakan jika di Indonesia setiap tahun terdapat $9.000 \mathrm{ibu}$ hamil positif HIV yang melahirkan bayi, berarti akan lahir sekitar 3.000 bayi dengan HIV positif tiap tahun. Ini akan terjadi jika tidak ada intervensi. Resiko penularan HIV dari ibu ke bayi berkisar 24-25\%. Namun, resiko ini dapat diturunkan menjadi $1-2 \%$ dengan tindakan intervensi bagi ibu hamil HIV positif, yaitu melalui layanan memberi konseling dan tes HIV sukarela, pemberian obat antiretroviral, persalinan sectio caesaria, serta pemberian susu formula untuk bayi ${ }^{3}$ Peningkatan jumlah kasus HIV/AIDS di Jawa Jawa Barat juga terjadi sangat pesat.
Sejak tahun 2000-2014 tercatat ada 2.922 kasus HIV/AIDS dengan korban meninggal sebanyak 406 orang (Suara Merdeka, 2014). AKB di Provinsi Jawa Barat tahun 2013 sebesar 283/1.000 kelahiran hidup, meningkat bila dibandingkan dengan tahun 2012 sebesar 212/1.000 kelahiran hidup (DinKes Prov Jawa Barat, 2013). Laporan sejumlah Lembaga Swadaya Masyarakat (LSM) yang peduli terhadap penyakit HIV/AIDS menunjukkan selama periode Januari-Maret 2010 tercatat 77 penderita HIV dan 9 penderita AIDS. ${ }^{4}$ Pada tahun 2013 telah terdapat 744 layanan klinik VCT yang tesebar di seluruh provinsi di Indonesia Klinik VCT hingga Juni 2013, telah dimanfaatkan oleh masyarakat dengan jumlah kunjungan yaitu 101.209 kunjungan, namun hanya $91,45 \%$ yang menyelesaikan pemeriksaan HIV tersebut dan $5,48 \%$ diantaranya dinyatakan HIV positif. ${ }^{5}$ Masalah HIV dan AIDS adalah masalah kesehatan masyarakat yang memerlukan perhatian yang sangat serius, ini terlihat dari apabila dilihat jumlah kasus AIDS yang dilaporkan setiap tahunnya sangat meningkat secara signifikan, dan yang lebih memprihatinkan penyebaran kasus HIV/AIDS tidak hanya terjadi pada warga beresiko, namun kaum ibu hamil menjadi sasaran empuk penyakit mematikan ini. Adanya banyak faktor-faktor yang mempengaruhi perilaku ibu hmail untuk memanfaatkan layanan pemeriksaan VCT di puskesmas, sehingga tidak seluruhnya ibu hamil memanfaatkan pelayanan tersebut. Secara umum teori Laurence Green menjelaskan perilaku di pengaruhi beberapa faktor seperti: (1). Faktor predisposing (motivasi, sikap, nilai, norma, dll), (2). Faktor enabling (prasarana, sarana, ketersediaan SDM (sumber informasi), dll), (3). Faktor reinforcing (peran/peran kader atau tenaga kesehatan yang berupa kompetensi yang dimiliki, toma, toga, dll), (4).lingkungan (sosial ekonomi, nilai budaya dll. ${ }^{6}$ Wilayah dengan pengidap HIV/AIDS yang cukup tinggi di Provinsi Jawa Barat, yang sejak 1998 hingga Maret 2010 ditemukan 476 kasus HIV dan 78 kasus AIDS, 17 diantaranya meninggal dunia. Berdasarkan data pesatnya peningkatan kasus HIV/AIDS di Kabupaten Garut disebabkan tingginya populasi pengguna narkotika, psykotropika dan zat adiktif (Napza) dengan menggunakan jarum suntik, sehingga mempercepat proses penularan penyakit tersebut. Di Kabupaten Garut pada tahun 2014 
kasus HIV/AIDS ditularkan melalui hubungan seksual (seksual transmisi), dengan jumlah kasus 328 HIV dan 113 AIDS dengan jumlah meninggal 10 orang. $^{7}$ Mereka lebih sering meninggalkan rumah dalam waktu yang lama. Jika perilaku seks mereka tidak sehat dapat menjadi resiko dalam penularan HIV/AIDS kepada istri dan bayinya jika sang istri sedang hamil, namun hal ini tidak mereka sadari karena kurangnya pengetahuan tentang perilaku yang beresiko tersebut. Berdasarkan pada hasil wawancara pada prapenelitian terhadap beberapa masyarakat di wilayah puskesmas Siliwangi. ${ }^{8}$ Fasilitas pelayanan adalah segala sesuatu yang dapat dipakai sebagai alat dalam mencapai maksud atau tujuan dalam memberikan bentuk layanan dan alat yang diartikan sebagai media. Sarana yang akan semakin bersemangat dalam menjaga kesehatan apabila banyak fasilitas penunjangnya. Fasilitas pelayanan tersebut tersedia dari yang termurah sampai yang termahal, dan dari yang paling sederhana (mudah diperoleh) sampai yang sulit diperoleh. Secara umum fasilitas adalah alat penunjang keberhasilan suatu proses upaya yang dilakukan di dalam pelayanan publik, karena apabila kedua hal ini tidak tersedua maka semua kegiatan yang dilakukan tidak akan dapat mencapai hasil yang di harapkan sesuai dengan rencana. Berkaitan dengan hal tersebut, Moenir mengemukakan bahwa fasilitas merupakan sarana yang di jelaskan sengan segala jenis peralatan, perlengkapan kerja dan fasilitas yang berfungsi sebagai alat utama/pembantu dalam pelaksanaan pekerjaan, dan juga dalam rangka kepentingan yang sedang berhubungan dengan organisasi kerja. Motivasi pada dasarnya adalah kondisi mental yang mendorong dilakukannya suatu tindakan (action/activities) dan memberikan kekuatan (energy) yang mengarah kepada pencapaian kebutuhan, memberi kepuasan, atau mengurangi ketidakseimbangan. Dengan demikian dapat dikatakan bahwa motivasi adalah sesuatu yang menimbulkan dorongan atau semangat terhadap satu aktivitas tertentu. Selain adanya ketersediaan fasilitas pelayanan, motivasi ibu hamil, sumber informasi yang mempengaruhi pemanfaatan layanan VCT. Faktor ekternal lainnya seperti peran kader mempengaruhi pula perilaku ibu hamil dalam pemanfaatan layanan VCT. Bentuk peran tersebut adalah dukungan berupa bantuan informasi, bantuan dorongan secara psikologis, atau dalam bentuk bantuan langsung. Kader adalah seorang tenaga sukarela yang direkrut dari, oleh dan untuk masyarakat, yang bertugas membantu kelancaran pelayanan kesehatan. Keberadaan kader sering dikaitkan dengan pelayanan rutin di posyandu. Sehingga seorang kader posyandu harus mau bekerja secara sukarela dan ikhlas, mau dan sanggup melaksanakan kegiatan posyandu, serta mau dan sanggup menggerakkan masyarakat untuk melaksanakan dan mengikuti kegiatan kesehatan diluar pelayanan. Kader kesehatan adalah tenaga sukarela yang dipilih oleh masyarakat dan bertugas mengembangkan masyarakat. Dalam hal ini kader disebut juga sebagai penggerak atau promotor kesehatan. Layanan VCT telah mencakup konseling pre tes, tes HIV dan konseling post tes belum di manfaatkan oleh masyarakat di wilayah Puskesmas Siliwangi. Masih berdasarkan hasil observasi pra penelitian, pola hidup sehat masyarakat. Pasangan usia subur masih disibukan dengan kegiatan sehari-hari, sehingga meremehkan fasilitasi layanan VCT. Sebagai masarakat menganggap bahwa pemanfaatan layanan VCT dapat dilakukan bila mengalami gajala sakit atau di temui tanda-tanda mencurigakan, namun ada sebagian orang juga yang menganggap bahwa tanda-tanda tersebut akan hilang dengan penggunaan obat yang rutin tanpa harus memanfaatkan layanan VCT. Banyak permasalahan yang kompleks pada kasus kesehatan masyarakat menjadi tanggung jawab bersama, sehingga seluurh masyarakat perlu berperan dalam mencapai status derajat sehat pada daerah, maka berdasarkan pada permasalahan tersebut mengingat derajat kesehatan menjadi tanggung jawab bersama, terlebih dalam menekan angka mortalitas dan mobilitas, hal ini pula di dasari pada hasil pra survey, menarik perhatian peneliti untuk melakukan penelitian tentang "Pengaruh sumber informasi, fasilitas pelayanan, peran kader dan motivasi ibu hamil terhadap perilaku pemanfaatan layanan Voluntary Counseling and Testing (VCT) di Puskesmas Siliwangi Kabupaten Garut Tahun 2015”. Tujuan untuk mengetahui pengaruh langsung dan tidak langsung serta besarannya antara sumber 
informasi, fasilitas pelayanan, peran kader dan motivasi ibu hamil terhadap perilaku pemanfaatan layanan Voluntary Counseling and Testing (VCT) di Puskesmas Siliwangi Kabupaten Garut tahun 2015.

\section{Metode}

Penelitian ini dilakukan dengan menggunakan metode penelitian kuantitatif dengan desain penelitian cross sectional dengan alasan bahwa penelitian ini dilakukan dalam kurun waktu yang bersamaan untuk mengetahui pengaruh antara sumber informasi, fasilitas pelayanan, peran kader dan motivasi ibu hamil terhadap perilaku pemanfaatan layanan Voluntary Conseling and Testing (VCT) oleh ibu hamil di Puskesmas Siliwangi Kabupaten Garut Tahun 2015. Penelitian ini dilaksanakan di Puskesmas Siliwangi Kecamatan Garut Kota Kabupaten Garut. Waktu penelitian dilaksanakan dalam kurun waktu satu bulan. Adapun kegiatan pengambilan data dilaksanakan pada bulan Januari 2016. Populasi adalah keseluruhan dari objek penelitian atau objek yang akan diteliti. ${ }^{9}$ Populasi dalam penelitian ini adalah seluruh ibu hamil di Puskesmas Siliwangi Kecamatan Garut Kota Kabupaten Garut sebanyak 5.230 ibu hamil. Sampel adalah sebagian dari jumlah dan karakteristik yang dimiliki oleh populasi tersebut. Bila populasi besar dan peneliti tidak mungkin mempelajari semua yang ada pada populasi. ${ }^{10}$ Model anlisis jalur semua variabel laten dalam PLS terdiri dari tiga set hubungan: Iner model yang spesifikasinya hubungan antar variabel laten (struktural model), diukur dengan menggunakan Q-square prediktif relepance dengan rumus $\mathrm{Q}^{2}=1-\left(1-\mathrm{R} 1^{2}\right) \quad(1-$ $\left.\mathrm{Rp}^{2}\right)$. Outer model yang mengsepsifikasikan hubungan antar variabel laten dengan indikatornya atau variabel manipestasinya (measurement model), diukur dengan melihat convergent validiti loading 0,5 sampai 0,6 dianggap cukup, untuk jumlah indikator dari variabel laten berkisar 3 sampai 7, sedangkan discriminant validiti direkomendasikan nilai AVE lebih besar dari 0,5 dan juga dengan melihat (3) weigh relation dimana nilai kasus dari variabel laten tetap diestimasi. Uji validitas dan reliabilitas dilakukan untuk mengetahui apakah instrumen yang dilakukan betul-betul mengukur apa yang perlu diukur dan sejauh mana instrumen yang digunakan dapat dipercaya atau diandalkan. Terlebih ahulu sebelum uji validitas dan reliabilitas indikator dari variabel, dilakukan uji validitas dan reliabilitas pada kuesioner dengan menggunakan SPSS. Uji validitas dan reliabilitas indikator dari variabel endogen dan eksogen dengan menggunakan Smart Partial Square (PLS), dinyatakan valid jika mempunyai loading faktor 0.5-0.6 (masih) dapat ditolelir sepanjang model masih dalam tahap pengembangan, namun loading faktor yang direkomendasikan di atas 0,7.

Model spesifikasi dengan smart PLS: Iner model (Iner Relation, struktural model dan substantive teori). Iner model atau disebut juga iner relation menggambarkan hubungan antar variabel laten berdasarkan pada teori. Model struktural dievaluasi dengan melihat nilai R-square untuk konstruk laten dependen, strobe disser $Q$-square test untuk prediktif relevance dan uji $\mathrm{T}$, serta signifikansi dan koefesien parameter jalur struktular. Outer model (outer relation atau measurement model). PLS adalah model persamaan strukturan (SEM) yang berbasis komponen atau varian (variance). PLS merupakan pendekatan alternatif yang bergeser dari pendekatan SEM berbasis convarience menjadi berbasis varian. SEM yang berbasis covarian umumnya menguji kausalitas / teori sedangkan PLS lebih bersifat predikatif model. Setelah data mentah (raw data) terkumpul, tahap selanjutnya adalah menyajikan data tersebut dalam berbagai bentuk: Penyajian yang disajikan pada awal hasil analisis adalah berupa gambaran atau deskripsi mengenai sampel, dimana penjelasan juga diserta ringkasan berupa tabel dari deskripsi yang utama. $^{11}$ Setelah data mentah (raw data) terkumpul, tahap selanjutnya adalah menyajikan data tersebut dalam berbagai bentuk: Penyajian yang disajikan pada awal hasil analisis adalah berupa gambaran atau deskripsi mengenai sampel, dimana penjelasan juga diserta ringkasan berupa tabel dari deskripsi yang utama. Hal ini dilakukan untuk membantu pembaca lebih mengenal karakteristik dari responden dimana data penelitian tersebut diperoleh. Data penyajian analisis SEM dari pengolahan data output yang menggunakan bantuan smartPLS 2.0, disajikan dalam diagram, tabel dan lain-lain. Penyajian data yang lebih lengkap akan disajikan dalam lampiran termasuk tampilan kuesioner. 


\section{Hasil}

Tabel 1. Nilai Distribusi Jawaban Responden Pada Konstruk Penelitian

\begin{tabular}{lcccccc}
\hline Variabel Penelitian & $\begin{array}{c}\text { Rentang } \\
\text { Teoritis }\end{array}$ & $\begin{array}{c}\text { Rata-Rata } \\
\text { Teoritis }\end{array}$ & $\begin{array}{c}\text { Rentang } \\
\text { Aktual }\end{array}$ & $\begin{array}{c}\text { Rata }- \text { Rata } \\
\text { Aktual }\end{array}$ & Range & $\begin{array}{c}\text { Standar } \\
\text { Deviasi }\end{array}$ \\
\hline Sumber informasi & $15-75$ & 45 & $22-57$ & 44,1 & 35 & 5,97 \\
Fasilitas pelayanan & $15-75$ & 45 & $24-58$ & 43,9 & 34 & 5,65 \\
Motivasi ibu & $15-75$ & 45 & $25-42$ & 48,9 & 38 & 6,67 \\
Peran kader & $15-75$ & 45 & $26-59$ & 45,4 & 33 & 6,65 \\
Perilaku pemanfaatan & $10-50$ & 35 & $16-49$ & 35,9 & 33 & 5,36 \\
\hline
\end{tabular}

Sumber: Data diolah dengan SPSS 18, 2016

Berdasarkan tabel diatas dapat disimpulkan bahwa konstruk sumber informasi terdapat rentang teoritis antara 15-75 dengan mendapatkan rata-rata 45. Dan pada rentang aktual terdapat nilai jawaban yang berkisar antara 22-57 yang memiliki rata-rata 44,1. Pada variabel sumber informasi memiliki standar deviasi sebesar 5,97. Pada tabel tersebut dapat diketahui bahwa konstruk fasilitas pelayanan memiliki rentang teoritis antara 15-75 dan mendapatkan nilai rata-rata sebesar 45. Pada rentang aktualnya kontruk fasilitas pelayanan memiliki nilai antara 24-58 dan mendapatkan nilai rata-rata sebesar 43,9. Setelah diolah konstruk memiliki nilai standar deviasi sebesar 5,65. Pada tabel tersebut dapat diketahui bahwa konstruk motivasi ibu memiliki rentang teoritis antara 15-75 dan mendapatkan nilai rata-rata sebesar 45 . Pada rentang aktualnya kontruk persepsi memiliki nilai antara 25-63 dan mendapatkan nilai ratarata sebesar 48,9. Setelah diolah konstruk motivasi ibu memiliki nilai standar deviasi sebesar 6,67. Peran kaderterdapat rentang teoritis antara 15-75 dan mendapatkan nilai rata-rata sebesar 45 . pada rentang aktualnya kontruk peran kader memiliki nilai antara 2649 dan mendapatkan nilai rata-rata sebesar 45,4. Setelah diolah variabel tersebut memiliki nilai standar deviasi sebesar 6,65. Perilaku pemanfaatan terdapat rentang teoritis antara 10-50 dan mendapatkan nilai rata-rata sebesar 35. pada rentang aktualnya kontruk perilaku pemanfaatan layanan VCT memiliki nilai antara 16-49 dan mendapatkan nilai rata-rata sebesar 35,9. Setelah diolah variabel tersebut memiliki nilai standar deviasi sebesar 5,36.

Analisis bivariat bertujuan untuk melihat hubungan distribusi dari karakteristik individu (umur, tingkat pendidikan) dan fasilitas pelayanan, sumber informasi, peran kader dan motivasi ibu hamil terhadap perilaku pemanfaatan layanan Voluntary Counseling and Testing (VCT). Kemudian masing-masing veriabel tersebut diatas akan dilakukan uji korelasi dengan masing-masing veriabel eksogen dan indogenfasilitas pelayanan, sumber informasi, peran kader dan motivasi ibu hamilmenggunakan alat uji chi square, karena semua veriabel tersebut berskala nominal dan ordinal.

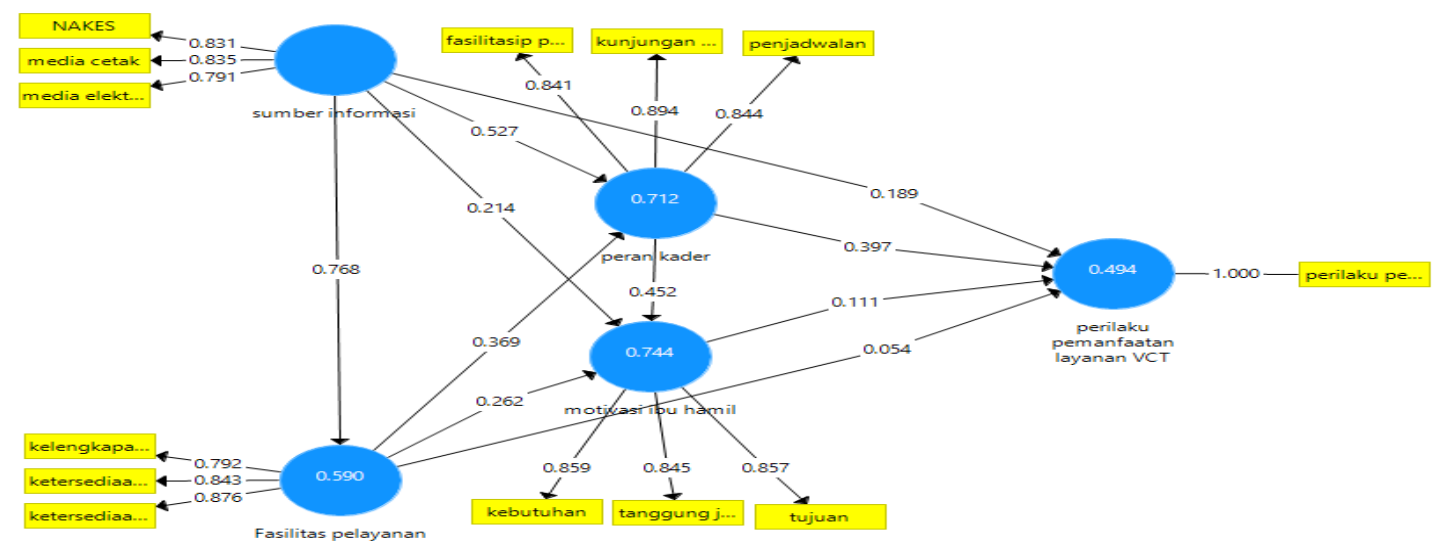

Gambar 1. Output PLS (Loading factor) 
Berdasarkan gambar diatas, terlihat bahwa nilai faktor loading telah memenuhi persyaratan yaitu nilai loading faktor di atas 0,5 . Suatu indikator reflektif dinyatakan valid jika mempunyai loading faktor di atas 0.5 terhadap konstruk yang di tuju berdasarkan pada substantive content nya dengan melihat dari weight $(\mathrm{T}=1,96)$. Inner model adalah pengujian dengan cara mengevaluasi antar konstruk laten yang telah dihipotesiskan dalam penelitian, dan dalam penelitian ini hipotesisnya adalah ada pengaruh sumber informasi, peran kader, motivasi ibu dan fasilitas pelayanan terhadap perilaku pemanfaatan layanan VCT yang masingmasing variabel diukur dengan tiga konstruk laten. Masing-masing variabel secara langsung dan tidak langsung mempengaruhi perilaku, yang digambarkan pada analisa jalur. Pengujian Inner model dilakukan setelah hasil pengujian outer model mendapatkan angka yang lebih besar dari angka yang di syaratkan. Pengujian inner model dilakukan dengan melakukan Bootstrappingyaitu prosedur atau teknik statistikresampling. Resampling berarti bahwa responden ditarik secara random dengan replacement, dari sampel original berkali-kali hingga diperoleh $\mathrm{n}$ observasi. Karena random dengan replacement maka ada kemungkinan respondenakan ditarik kembali sebagai sampel. Bootstrapping memiliki keunggulan tidak membutuhkan asumsi mengenai distribusi suatu statistik tertentu, misalnya asumsi normalitas.

Berdasarkan pada tabel 2 dibawah, di jelaskan bahwa variabel sumber informasi, peran kader, motivasi ibu hamil, fasilitas pelayanan terhadap perilaku pemanfaatan sebesar 0,494 atau 49,4\% sehingga ada 50,6\% faktor lain selain variabel tersebut, sedangkan sumber informasi dan fasilitas pelayanan terhadap peran kader di dapat nilai $\mathrm{R}$ 0,712atau $71,2 \%$ sehingga masih banyak faktor lain yang mempengaruhi peran kader sebanyak 28.1.sumber informasi, peran kader, dan fasilitas pelayanan terhadap motivasi sebesar 0,744 atau $74,4 \%$, dan ada faktor lain sebesar $25,5 \%$.

Tabel 2. Hasil Pengukuran R-Square Dari Sumber Informasi, Peran Kader, Motivasi Ibu Hamil, Dan Fasilitas Pelayanan Terhadap Perilaku Pemanfaatan VCT

\begin{tabular}{lc}
\hline & - Square \\
\hline Fasilitas pelayanan & 0,590 \\
Motivasi ibu hamil & 0,744 \\
Peran kader & 0,712 \\
\hline Perilaku pemanfaatan layanan & $\mathbf{0 , 4 9 4}$ \\
VCT & \\
\hline Sumber: Hasil olah data penelitian Tahun 2016
\end{tabular}

Berdasarkan tabel 3 tersebut dibawah, dinyatakan bahwa pengaruh sumber informasi terhadap perilaku pelayanan VCT, hasil uji koefisien parameter antara sumber informasi terhadap perilaku pemanfaatan sebesar $12,077 \% \%$ untuk pengaruh langsung, dan untuk pengaruh tidak langsung mendapatkan nilai sebesar $0,043 \%$ melalui variabel peran kader dan motivasi ibu hamil. Peran kader terhadap perilaku pemanfaatan layanan VCT melalui hasil uji koefisien parameter sebesar $27,154 \%$, dan dalam penelitian mengukur pengaruh secara tidak langsung antara motivasi kerja terhadap beban tugas kerja melalui persepsi dengan nilai sebesar $0,027 \%$ melalui variabel motivasi ibu hamil.

Tabel 3. Presentase Besaran Pengaruh Langsung dan Tidak Langsung Sumber Informasi, Peran Kader, Motivasi Ibu Hamil, Dan Fasilitas Pelayanan Terhadap Perilaku Pemanfaatan VCT Kabupaten Garut Tahun 2015

\begin{tabular}{|c|c|c|c|c|c|c|c|}
\hline \multirow[t]{2}{*}{ Variabel } & LV & \multirow{2}{*}{$\begin{array}{l}\text { Direct } \\
\text { path }\end{array}$} & \multirow{2}{*}{$\begin{array}{l}\text { Indirect } \\
\text { rho }\end{array}$} & \multirow[t]{2}{*}{ Total } & \multirow{2}{*}{$\frac{\text { Direct }}{\%}$} & \multirow{2}{*}{$\frac{\text { Indirect }}{\%}$} & \multirow{2}{*}{$\begin{array}{l}\text { Total } \\
\%\end{array}$} \\
\hline & correlation & & & & & & \\
\hline sumber informasi & 0,639 & 0,189 & 0,303 & 0,213 & 12,077 & 0,043 & 12,12 \\
\hline peran kader & 0,684 & 0,397 & 0,051 & 0,443 & 27,154 & 0,027 & 27,181 \\
\hline motivasi ibu hamil & 0,629 & 0,111 & & 0,111 & 6,981 & & 6,981 \\
\hline fasilitas pelayanan & 0,593 & 0,054 & 0,147 & 0,06 & 3,32 & 0,039 & 3,359 \\
\hline Total & & & & 0,827 & 49,439 & 0,109 & 49,641 \\
\hline
\end{tabular}

Sumber :Outputyang diolah Program SmartPLS 20, 2016 
Motivasi ibu hamil terhadap perilaku pemanfaatan layanan VCT berdasarkan hasik uji koefiesien parameter, Hasil pengujian tersebut ditunjukan dengan nilai sebesar $6,981 \%$ untuk pengaruh langsung, sedangkan untuk pengaruh tidak langsung tidak diteliti dalam penelitian ini. Hasil uji parameter koefisien antara fasilitas pelayanan terhadap perilaku pemanfaatan layanan VCT menunjukan terdapat pengaruh langsung terhadap beban tugas kerja sebesar 3,32\%, dan mengukur pengaruh tidak langsung antara kedua nya dengan nilai sebesar $0,039 \%$.

Berdasarkan perhitungan secara keseluruhan, dari masing-masing pengaruh langsung variabel laten eksogen tersebut apabila secara bersama sama menunjukan kesesuaian dengan R Squere atau dengan kata lain menunjukan bahwa sumber informasi, peran kader, motivasi, dan fasilitas pelayanan terhadap perilaku pemanfaatan layanan VCT sebesar $12,077+0,043+27,154+0,027+6,981+$ $3,32+0,039=49,641$. Hal tersebut menunjukan model hasil analisis dapat menjelaskan 96,43\% keragaman data dan mampu mengkaji fenomena yang dipakai dalam penelitian, sedangkan 3,56\% dijelaskan komponen lain yang tidak ada dalam penelitian ini ditempatkan sendiri masih ada 3,56\% variabel yang bisa dielaborasi.

\section{Pembahasan}

\section{Pengaruh Sumber Informasi terhadap Perilaku Pemanfaatan Layanan Voluntary Counseling and Testing (VCT) di Puskesmas Siliwangi Kabupaten Garut tahun 2015}

Hasil pengujian terhadap koefisien parameter antara pengaruh sumber informasi terhadap perilaku pemanfaatan layanan Voluntary Counseling and Testing (VCT) di Puskesmas Siliwangi Kabupaten Garut tahun 2015menunjukan ada pengaruh langsung sebesar 12,198\%, sedangkan pengaruh tidak langsung antara sumber informasi terhadap perilaku pemanfaatan layanan Voluntary Counseling and Testing (VCT) di Puskesmas Siliwangi Kabupaten Garut tahun 2015 adalah sebesar $14,46 \%$, melalui peran kader dan motivasi ibu hamil. Nilai $\mathrm{T}$ statistik yang di dapatkan dalam menggambarkan hubungan antara sumber informasi terhadap perilaku pemanfaatan layanan Voluntary Counseling and Testing (VCT) di Puskesmas Siliwangi Kabupaten Garut tahun 2015 adalah sebesar
2,156 berdasarkan hasil uji tersebut dapat di jelaskan bahwa ada pengaruh langsung sumber informasi terhadap perilaku pemanfaatan layanan VCT lebih besar dari pengaruh tidak langsung antara sumber informasi terhadap perilaku pemanfaatan layanan Voluntary Counseling and Testing (VCT) di Puskesmas Siliwangi Kabupaten Garut tahun 2015, sehingga di nyatakan sumber informasi mempengaruhi perilaku pemanfaatan layanan VCT di puskesmas wilayah VII Kabupaten Garut tahun 2015 bila melibatkan peran kader dan motivasi ibu hamil. Alasan mengapa menggunakan media informasi agar materi atau pesan yang disampaikan dapat mudah dimengerti oleh khalayak orang banyak, adapun alasan lain yaitu untuk menyederhanakan pesan, mengurangi verbalistis, menyamakan persepsi, menarik perhatian dan menghemat waktu. ${ }^{12}$

Perilaku dengan tindakan atau aktivitas dari manusia itu sendiri yang mempunyai bentangan yang sangat luas antara lain : berjalan, berbicara, menangis, tertawa, bekerja, kuliah, menulis, membaca, dan sebagainya. Dari uraian ini dapat disimpulkan bahwa yang dimaksud perilaku manusia adalah semua kegiatan atau aktivitas manusia, baik yang diamati langsung, maupun yang tidak dapat diamati oleh pihak luar. ${ }^{13}$

Hasil penelitian ini diperkuat oleh hasil penelitian yang dilakukan oleh Dina Aprilia dengan judul Hubungan Sumber Informasi Dengan Perilaku Seksual Berisiko Remaja Di Kecamatan Sumbersari Kabupaten Jember penelitian ini adalah probabilitysampling dengan sampel total sebanyak 110 responden. Data dianalisis dengan uji Spearman. Hasil uji menunjukkan nilai P $0,042(0,042<\alpha=0,05)$, sehingga dapat disimpulkan bahwa terdapat ubungan antara sumber informasi dengan perilaku seksual berisiko remaja di Kecamatan Sumbersari Kabupaten Jember.

Berdasarkan asumsi peneliti, bahwa perilaku timbul di sebabkan adanya rangsangan atau stmulus, sehingga dengan adanya rangasangan ini, akan berdampak pada timbul nya perilaku atau tindakan, sedangkan sumber informasi adalah sumber yang dapat di jadikan ukuran tahu tentang sesuatu sehingga dapat di jadikan sebagai pegangan untuk melakukan tindakan. Ibu hamil dengan mendapatkan informasi yang jelas tentang 
layanan VCT dari sumber informasi yang di percaya akan berdampak pada pengambilan tindakan .

\section{Pengaruh Fasilitas Pelayanan terhadap Perilaku Pemanfaatan Layanan Voluntary Counseling and Testing (VCT) di Puskesmas Siliwangi Kabupaten Garut tahun 2015}

Hasil pengujian terhadap koefisien parameter antara pengaruh fasilitas pelayanan terhadap perilaku pemanfaatan layanan Voluntary Counseling and Testing (VCT) di Puskesmas Siliwangi Kabupaten Garut tahun 2015menunjukan ada pengaruh langsung sebesar 3,32, sedangkan pengaruh tidak langsung antara fasilitas pelayanan terhadap perilaku pemanfaatan layanan Voluntary Counseling and Testing (VCT) di Puskesmas Siliwangi Kabupaten Garut tahun 2015adalah sebesar 0,104, melalui motivasi dan peran kader. Nilai $\mathrm{T}$ statistik yang di dapatkan dalam menggambarkan hubungan antara fasilitas pelayanan terhadap perilaku pemanfaatan layanan Voluntary Counseling and Testing (VCT) di Puskesmas Siliwangi Kabupaten Garut tahun 2015 adalah sebesar 2,394 berdasarkan hasil uji tersebut dapat di jelaskan bahwa ada pengaruh tidak langsung fasilitas pelayanan terhadap perilaku pemanfaatan layanan Voluntary Counseling and Testing (VCT) di Puskesmas Siliwangi Kabupaten Garut tahun 2015, pengaruh tidak langsung melibat kan pada variabel peran kader dan motivasi ibu hamil.

Hasil penelitian menunjukan ada pengaruh antara fasilitas pelayanan secara langsung dan tidak langsung mempengaruhi perilaku pemanfaatan layanan VCT, secara langsung maupun tidak langsung. Melalui motivasi ibu hamil dan peran kader. Sehingga terdapat fasilitas yang memadai sesuai dengan standar layanan VCT akan berdampak pada masyarakat mau memanfaatkan layanan tersebut. Faktor fasilitas pelayanan merupakan faktor yang mempengaruhi terhadap rendahnya layanan VCT, hal ini terlihat dari rendahnya kunjungan dari masyarakat yang menggunakan layanan VCT kurang memperhatikan pripasi klien sehingga ibu tidak mau melakukan layanan VCT. Di lapangan sebanyak 60\% ibu

hamil enggan untuk melakukan layanan VCT karena malu untuk diperiksa dikarenakan tempatnya tidak nyaman. Fasilitas adalah alat penunjang keberhasilan suatu proses upaya yang dilakukan di dalam pelayanan masyarakat, karena apabila hal ini tidak tersedia maka semua pelayanan kegiatan yang dilakukan tidak akan memenuhi target yang diharapkan seseuai dengan perencanaan.

Mendasari hal tersebut, fasilitas pelayanan VCT sangat berperan dalam mendorong ibu untuk termotivasi menggunakan layanan. Mengingat motivasi merupakan hal yang perlu mendapatkan stimulus dan mengarahkan pada tindakan. Motivasi adalah proses yang terjadi dalam diri yang menciptakan tujuan dan memberikan tenaga bagi tingkahlaku seseorang iaitu daya penggerak yang ada di dalam diri seseorang untuk melakukan aktiviti-aktiviti tertentu demi mencapai suatu tujuan. ${ }^{14}$

Hasil penelitian tersebut senada dengan hasil penelitian yang dilakukan oleh Sari, dengan hasil penelitian menunjukkan bahwa variabel kualitas pelayanan memberikan pengaruh secara parsial dan simultan terhadap kepuasan konsumenvariabel fasilitas memberikan pengaruh secara parsial dan simultan terhadap kepuasan konsumen, variabel persepsi harga memberikan pengaruh secara parsial dan simultan terhadap kepuasan konsumen, variabel lokasi memberikan pengaruh secara parsial dan simultan terhadap kepuasan konsumen. Hasil analisis regresi diperoleh persamaan : $\mathrm{Y}^{\wedge}=2,994-0,063 \mathrm{X} 1-$ 0,094 X2+1,038 X3+0,301 X4. Uji keberartian persamaan regresi dengan analisis varian untuk regresi diperoleh $\mathrm{F}$ hitung $=204,329$ dengan harga signifikansi sebesar 0,000. Dengan demikian menunjukkan bahwa kualitas pelayanan, fasilitas, persepsi harga, dan lokasi berpengaruh terhadap kepuasan konsumen. Hasil uji secara parsial diperoleh thitung untuk variabel kualitas pelayanan sebesar -2,673 dengan signifikansi 0,009 , untuk variabel fasilitas diperoleh thitung sebesar $-2,526$ dengan signifikansi 0,013 untuk variabel persepsi harga diperoleh thitung sebesar 18,472 dengan signifikansi 0,000 dan untuk variabel lokasi diperoleh thitung sebesar 10,219 dengan signifikansi 0,000 . Hal ini menunjukkan bahwa secara parsial kualitas pelayanan, fasilitas.

Asumsi peneliti, fasilitas adalah dorongan yang menggerakan seseorang ke arah perilaku tertentu sehingga dapat mencapai tujuan tertentu sesuai yang diinginkan. segala 
jenis peralatan, perlengkapan kerja dan fasilitas pendukung yang berfungsi sebagai alat utama/pembantu dalam pelaksanaan pekerjaan, dan dapat digunakan sebagai alat mencapai tujuan. Dengan indikator kelengkapan sarana, ketersediaan kendaraan dan ketersediaan tenaga kesehatan.

\section{Pengaruh Peran Kader terhadap Perilaku Pemanfaatan Layanan Voluntary Counseling and Testing (VCT) di Puskesmas Siliwangi Kabupaten Garut tahun 2015}

Hasil pengujian terhadap koefisien parameter antara pengaruh peran kader terhadap perilaku pemanfaatan layanan Voluntary Counseling and Testing (VCT) di Puskesmas Siliwangi Kabupaten Garut tahun 2015menunjukan ada pengaruh langsung sebesar 26,94\%, sedangkan pengaruh tidak langsung antara peran kader terhadap perilaku pemanfaatan layanan Voluntary Counseling and Testing (VCT) di Puskesmas Siliwangi Kabupaten Garut tahun 2015 dan nilai pengaruh tidak langsung melalui variabel motivasi ibu di dapat nilai sebesar 0,86.

Nilai T statistik yang di dapatkan dalam menggambarkan hubungan antara peran kader terhadap perilaku pemanfaatan layanan Voluntary Counseling and Testing (VCT) di Puskesmas Siliwangi Kabupaten Garut tahun 2015 adalah sebesar 2,929 berdasarkan hasil uji tersebut dapat di jelaskan bahwa ada pengaruh tidak langsung peran kader lebih besar pengaruh langsung dari pada pengaruh tidak langsung melalui variabel motivasi, sehingga di nyatakan peran kader terhadap perilaku pemanfaatan layanan Voluntary Counseling and Testing (VCT) di Puskesmas Siliwangi Kabupaten Garut tahun 2015memiliki pengaruh yang baik bila melibatkan motivasi.

Perilaku kesehatan tidak terlepas dari pada kebudayaan masyarakat. Dalam upaya untuk menumbuhkan partisipasi masyarakat harus pula diperhatikan keadaan sosial budaya masyarakat. Sehingga untuk mengikut sertakan masyarakat dalam upaya pembangunan, khususnya dalam bidang kesehatan, tidak akan membawa hasil yang baik bila prosesnya melalui pendekatan yang edukatif yaitu, berusaha menimbulkan kesadaran untuk dapat memecahkan permasalahan dengan memperhitungkan sosial budaya setempat. ${ }^{15}$
Dengan terbentuknya kader kesehatan, pelayanan kesehatan yang selama ini dikerjakan oleh petugas kesehatan saja dapat dibantu oleh masyarakat. Dengan demikian masyarakat bukan hanya merupakan objek pembangunan, tetapi juga merupakan mitra pembangunan itu sendiri. Selanjutnya dengan adanya kader, maka pesan-pesan yang disampaikan dapat diterima dengan sempurna berkat adanya kader, jelaslah bahwa pembangunan kader adalah perwujudan pembangunan dalam bidang kesehatan.

Ciri-ciri tersebut juga berhubungan dengan status seseorang dalam lingkungan masyarakat. Dalam lingkungan perumahan seperti disebutkan Turner (dalam Panudju,1999), tanpa kejelasan tentang status kepemilikan hunian dan lahannya seseorang atau sebuah keluarga akan selalu tidak merasa aman sehingga mengurangi minat mereka untuk memelihara lingkungan tempat tinggalnya. Dalam hal ini status hunian seseorang akan berpengaruh pada tingkat peran sertanya dalam kegiatan bersama untuk memperbaiki lingkungan. Dalam masyarakat terdapat pembedaan kedudukan dan derajat atas dasar senioritas, sehingga akan muncul golongan tua dan golongan muda, yang berbeda dalam hal-hal tertentu, misalnya menyalurkan pendapat dan mengambil keputusan. Faktor usia tentunya memiliki pengaruh terhadap kemampuan seseorang untuk berperan serta. Penemuan menunjukkan bahwa ada hubungan antara usia dengan keanggotaan seseorang untuk ikut dalam suatu kelompok atau organisasi. Selain itu beberapa fakta menunjukkan bahwa usia berpengaruh pada keaktifan seseorang untuk berperan serta. Faktor pendidikan dianggap penting karena dengan melalui pendidikan yang diperoleh, seseorang lebih mudah berkomunikasi dengan orang luar, dan cepat tanggap terhadap inovasi. Dengan demikian dapat dipahami bila ada hubungan antara tingkat pendidikan dan peran serta. Sedangkan faktor jenis pekerjaan berpengaruh pada peran serta karena mempengaruhi derajat aktifitas dalam kelompok dan mobilitas individu.

Besarnya tingkat pendapatan akan memberi peluang lebih besar bagi masyarakat untuk berperan serta. Tingkat pendapatan ini mempengaruhi kemampuan finansial masyarakat untuk berinvestasi. Besarnya biaya investasi yang akan dilakukan oleh masyarakat 
tidak semata-mata bergantung kepada kemampuan menanamkan uangnya, tetapi juga pada keuntungan dan kepuasan dari apa yang akan mereka dapatkan dari investasi tersebut. Masyarakat hanya akan bersedia untuk mengerahkan semua kemampuannya apabila hasil yang dicapai akan sesuai dengan keinginan dan prioritas kebutuhan mereka.

Peran serta masyarakat hanya akan terjadi bila sejumlah warga dalam unit geografi tertentu merupakan sebuah komunitas atau minimal merupakan sebuah kelompok kepentingan yang akan dilayani oleh adanya peran serta tersebut. Kelompok ini merupakan wujud dari interaksi sosial antar warga. Suatu kelompok memperoleh bentuknya dari kesadaran akan keterikatan pada anggotaanggotanya. Suatu kelompok bukan merupakan jumlah anggotanya saja, akan tetapi mempunyai suatu ikatan psikologis. Adanya suatu kebutuhan psikologis manusia untuk mempunyai dan digolongkan pada suatu kelompok, tempat ia berlindung dan merasa aman. Semakin banyak orang berinteraksi semakin kuat ikatan psikologisnya dengan lingkungan di sekitarnya. Dalam hal ini semakin banyak jumlah tetangga yang dikenal maka semakin tinggi ikatan psikologisnya dengan lingkungan yang berpengaruh pada besarnya keinginan untuk terlibat dalam kegiatan bersama.

Hasil penelitian diperkuat oleh hasil penelitian yang dilakukan oleh Ditha Ariesya Pradan dengan Judul penelitian Pengaruh Pendidikan Kesehatan Oleh Kader Terhadap Praktek Ibu Dalam Pemberian Mp-Asi Di Wilayah Kerja Puskesmas Ledokombo Kabupaten Jember, dan hasil menunjukan hasil penelitian menunjukan bahwa ibu yang memiliki praktek pemberian MP-ASI kurang telah berkurang dari 18 responden $(54,5 \%)$ sebelum kader memberikan pendidikan kesehatan menjadi 11 responden $(33,3 \%)$ setelah kader memberikan pendidikan kesehatan. Ibu yang memiliki praktek pemberian MPASI baik meningkat dari 15 responden $(45,5 \%)$ pada saat kader belum memberikan pendidikan kesehatan menjadi 22 responden $(66,7 \%)$ setelah kader memberikan pendidikan kesehatan. Pengujian statistika menggunakan SPSS 16.0 menunjukan $\mathrm{p}$ value 0,011 dengan alpha 0,05 atau $5 \%$. Nilai $p$ value yang didapat dari hasil uji statistik adalah $\leq$ 0,05 dan berada pada nilai kemaknaan $0,01 \leq \mathrm{p}$
$<$ 0,05 maka H0 ditolak, sehingga dapat disimpulkan terdapat pengaruh pendidikan kesehatan oleh kader terhadap praktek ibu dalam pemberian MP-ASI ASI di wilayah kerja Puskesmas Ledokombo.

Asumsi peneliti, bahwa tindakan yang dilakukan oleh tenaga sukarela (kader) dalam membantu kegiatan pelaksanaan layanan VCT. Hal ini diukur dengan indikator membantu penjadwalan, membantu penyelenggaraan, dan memfasilitasi pertemuan. Pengukuran ini akan berdampak pada perilaku ibu hamil untuk memanfaatkan layanan tersebut.

\section{Pengaruh Motivasi Ibu Hamil terhadap Perilaku Pemanfaatan Layanan Voluntary Counseling and Testing (VCT) di Puskesmas Siliwangi Kabupaten Garut tahun 2015}

Hasil pengujian terhadap koefisien parameter antara pengaruh motivasi ibu hamil terhadap perilaku pemanfaatan layanan Voluntary Counseling and Testing (VCT) di Puskesmas Siliwangi Kabupaten Garut tahun 2015menunjukan ada pengaruh langsung sebesar $6,981 \%$, sedangkan tidak ada pengaruh tidak langsung antara motivasi ibu hamil terhadap perilaku pemanfaatan layanan Voluntary Counseling and Testing (VCT) di Puskesmas Siliwangi Kabupaten Garut tahun 2015. Nilai T statistik yang di dapatkan dalam menggambarkan hubungan antara motivasi ibu hamil terhadap perilaku pemanfaatan layanan Voluntary Counseling and Testing (VCT) di Puskesmas Siliwangi Kabupaten Garut tahun 2015adalah sebesar 2,552 berdasarkan hasil uji tersebut dapat di jelaskan bahwa ada pengaruh tidak langsung motivasi ibu hamil terhadap perilaku pemanfaatan layanan Voluntary Counseling and Testing (VCT) di Puskesmas Siliwangi Kabupaten Garut tahun 2015.

Berdasarkan hasil uji tersebut, dapat di jelaskan bahwa pengaruh motivasi terhadap perilaku secara langsung memiliki nilai lebih rendah dari pengaruh motivasi terhadap perilaku secara tidak langsung, dengan nilai korelasi sebesar 0.171 atau $17,1 \%$, sehingga berdasarkan hasil ini di sebutkan bahwa ada pengaruh langsung dan tidak langsung antara motivasi terhadap perilaku pemanfaatan layanan VCT.

Perilaku pemanfaatan layanan VCT, merupakan tindakan yang menunjukan adanya kaitan antara sehat atau sakit.Skinner adalah 
suatu respon seseorang (organisme) terhadap stimulus atau objek yang berkaitan dengan sakit dan penyakit, sistem pelayanan kesehatan, makanan, minuman dan lingkungan. ${ }^{16}$

Memanfaatkan merupakan perilaku dengan mengambil peran langsung, sehingga dalam aplikasinya keikut sertaan kegiatan layanan VCT merupakan partisipasi secara langsung ibu hamil terhadap kegiatan kesehatan, hal ini tentu menyangkut pada kepatuhan ibu hamil dalam menjaga kesehatan dengan melakukan upaya-upaya yang dapat meningkatkan wawasan kesehatan kehamilan serta dapat memotivasi pada aplikasi dalam upaya tersebut.

Memanfaatkan merupakan salah satu perilaku sehat, dengan tujuan menghindari terjadinya kesakitan dan terjadi nya kematian sebagai dampak terburuknya. Sehingga faktorfaktor yang mempengaruhi ibu hamil ikut serta atau tidak nya dalam pemanfaatan layanan VCT adalah sama hal nya dengan faktor-faktor terjadinya kepatuhan dalam menghindari terjadi nya penyakit.

Motivasi ibu hamil mempengaruhi perilaku pemanfaaan layanan VCT, hal ini mendasari pada konsep motivasi daya dalam diri sebagai penggerak, pendorong, Memanfaatkan merupakan perilaku dengan mengambil peran langsung, sehingga dalam aplikasinya keikut sertaan kelas ibu hamil merupakan partisipasi secara langsung melalui daya penggerak dalam mengambil peran langsung manfaat kelas ibu hamil.

Adapun cara ukur dari variabel motivasi adalah dengan mengajukan pertanyaan menggunakan kuesioner terstruktur tentang motivasi sehat yang terdiri dari 15 pertanyaan dan 5 pilihan jawaban, yang berisi indikatorindikator dari motivasi sehat sesuai dengan teori dan kondisi di lapangan. Skala yang digunakan dalam mengukur motivasi ini dengan skala semantic differensial yaitu skala untuk mengukur motivasi dan bentuknya adalah pilihan ganda yang tersusun dalam satu garis kontinum, yaitu buruk, sangat baik, tidak pernah, selalu, jawaban negatif disebelah kiri kolom dan jawaban positif di kolom sebelah kanan. Data yang diperoleh melalui pengukuran dengan skala semantic differensial adalah data interval. Pengolahan melalui dapat dilakukan dengan menilai pertanyaan sikap seseorang. Pertanyaan motivasi adalah serangkaian kalimat yang mengatakan sesuatu mengenai obyek motivasi yang hendak diungkap. mendukung sama sekali obyek motivasi.

Hasil penelitian diperkuat oleh hasil penelitian I Gusti Agung Ayu maya dengan judul penelitian pengaruh motivasi, disiplin kerja dan komunikasi terhadap kinerja karyawan pada pt. pln (persero) distribusi bali. Dengan hasil penelitian hasil analisis menunjukan ada variabel motivasi, disiplin kerja, dan komunikasi berpengaruh signifikan secara simultan dan parsial terhadap kinerja karyawan pada. Variabel motivasi menjadi variabel yang berpengaruh dominan terhadap kinerja karywan karena berdasarkan perhitungan analisis standardized coefficients beta memiliki nilai terbesar. Kata kunci: motivasi, disiplin kerja, komunikasi, kinerja karyawan.

Berdasarkan asumsi peneliti, bahwa motivasi adalah dorongan yang beradal dari dalam diri seseorang, yang dapat menggerakkan seorang melakukan tindakan daya dalam diri sebagai penggerak, pendorong, yang melatar belakangi tingkah laku atau bertindak. Dapat di jelaskan sebagai alasan menjalankan tingkah laku juga, mengarahkan pada perilaku pada kegiatan mencapai tujuan yang di sepakati.

\section{Kesimpulan}

Berdasarkan hasil kesimpulan variabel peran kader mempunyai nilai paling besar dalam mempengaruhi perilaku pemanfaatan VCT, dengan peran kader yang aktif dapat meningkatkan motivasi ibu hamil untuk dapat memanfaatkan layanan VCT dengan baik dan teratur.

\section{Saran}

Berdasarkan pada hasil penelitian di atas, dimana telah membuktikan adanya pengaruh pengaruh sumber informasi, peran kader, motivasi ibu hamil dan fasilitas pelayanan terhadap perilaku pemanfaatan layanan VCT, pengaruh langsung antara peran kader terhadap perilaku pemanfaatan layanan VCT di dapat temuan angka tertinggi dengan nilai pengaruh langsung sebesar 27,154\%, maka saran peneliti adalah, Berdasarkan pada hasil temuan di atas, maka peneliti memberikan referensi atau saran sebagai berikut; Meningkatkan peran kader dengan 
melakukan pelatihan layanan VCT berbasis masyarakat untuk mendeteksi sasaran VCT di wilayah kerjanya. Pihak puskesmas mengembangkan layanan VCT dengan melibatkan kader untuk berperan aktif dalam pelayanan VCT, dengan memberikan reward yang didanai dari dana BOK. Adanya kerjasama dengan media cetak lokal atau daerah untuk mempromosikan layanan VCT serta adanya kontribusi dari media cetk untuk dapa membantu meningkatkan pengetahuan masyarakat tentang layanan VCT.

\section{Daftar Pustaka}

1. Kemenkes RI. Bantuan Operasional Kesehatan. Jakarta : Kemenkes RI; 2014.

2. Kemenkes RI. Profil Kesehatan Indonesia. Jakarta : Kemenkes RI; 2011.

3. Depkes RI. Pedoman Umum Pengelolaan Posyandu. Bekerjasama dengan Kelompok Kerja Operasional (POKJANAL). Jakarta; 2006.

4. Dinkes Jawa Barat. Profil kesehtan. Dinkes Jawa Barat : 2013

5. Kemenkes RI. Survei Demografi dan Kesehatan Indonesia. Jakarta: Kemenkes RI ; 2013.

6. Notoatmodjo S. Pengantar Pendidikan dan Ilmu Perilaku Kesehatan. Jakarta: Andi Offset; 2007.
7. Diskes Garut. Profil Kesehatan. Diskes; 2014.

8. Profil puskesmas Siliwangi. Profil Kesehatan. Garut; 2004.

9. Nursalam. Metodologi Penelitian Ilmu Keperawatan. Jakarta: Salemba Medika ; 2008.

10. Sugiono D. Metode Penelitian Kuantitatif Kualitatif Dan R\&D. Bandung : Alfabeta ; 2008.

11. Ghozali I. Structural Equation Modeling Teori, Konsep dan Aplikasinya dengan Program Lisrel 8.80. Edisi II, Semarang: Badan Penerbit Universitas Diponegoro; 2008.

12. Alex SN. Manajemen Personalia (Manajemen Sumber Daya Manusia,Edisi Kelima, Cetakan Keempat belas, Jakarta: Ghalia Indonesia; 2005.

13. Notoatmodjo S. Promosi Kesehatan Teori dan Aplikasi. Jakarta: Rineka Cipta; 2003.

14. Nyoman. Teori Motivasi dan Aplikasinya, Edisi Ketiga, Jakarta: Rineka Cipta ;2008.

15. Basuni. Konsep Pengaturan Sumberdaya Manusia. Jakarta: Media Konservasi; 2012.

16. Hafizurrahman HM. Manajemen Pendidikan dan Kesehatan. Jakarta: Sagung Seto ; 2009. 